\title{
A new mutation of the MEN1 gene in an Italian kindred with multiple endocrine neoplasia type 1
}

\author{
F Cetani, E Pardi, L Cianferotti, E Vignali, A Picone, P Miccoli ${ }^{1}$, A Pinchera and C Marcocci \\ Dipartimento di Endocrinologia e Metabolismo, Ortopedia e Traumatologia, Medicina del Lavoro and ${ }^{1}$ Dipartimento di Chirurgia, Università di Pisa, \\ Pisa, Italy \\ (Correspondence should be addressed to C Marcocci, Dipartimento di Endocrinologia e Metabolismo, Ortopedia e Traumatologia, Medicina del Lavoro, \\ Università di Pisa, Via Paradisa 2, 56124 Pisa, Italy)
}

\begin{abstract}
Objective: To report a new mutation of the multiple endocrine neoplasia type 1 (MEN1) gene in an Italian kindred.

Design: The study included the female proband, aged 50 years, affected by primary hyperparathyroidism, insulinoma and prolactinoma, and ten relatives. Blood samples were obtained for biochemical and genetic analyses. Clinical screening tests included serum glucose, ionized calcium, intact parathyroid hormone, GH, insulin and prolactin. The coding sequence, including nine coding exons and 16 splice sites, was amplified by PCR and directly sequenced.

Results: Two additional cases of primary hyperparathyroidism were identified among the paternal family members. The sequence analysis showed a heterozygous $\mathrm{T}$ to $\mathrm{C}$ transition at codon 444 in exon 9, resulting in a leucine to proline substitution (L444P) in the patient and in the two paternal family members with primary hyperparathyroidism. The L444P amino acid change was absent in 50 normal subjects. The mutation determined the loss of a BlnI restriction site of the wild-type sequence and the creation of a new restriction EcoRII site. The patient, but not her paternal affected relatives, also had a common heterozygous polymorphism (D418D) in exon 9.

Conclusions: A new MEN1 mutation (L444P) in exon 9 has been identified; this substitution caused the loss of a BlnI restriction site and the creation of a new EcoRII site.

European Journal of Endocrinology 140 429-433
\end{abstract}

\section{Introduction}

Multiple endocrine neoplasia type 1 (MEN1) is an autosomal dominant disorder characterized by the combined occurrence of tumors of parathyroid glands, pancreatic islet cells and the anterior pituitary (1). Less frequently, tumors of the foregut, carcinoid and lipoma can be present. The MEN1 gene has been recently cloned on chromosome $11 \mathrm{q} 13(2,3)$ and encodes a novel 610 amino acid protein, termed 'MENIN'. The functional role of MENIN, which does not have similarities to any previously known protein, remains to be elucidated. Preliminary data suggest a nuclear localization of MENIN (4). Germline mutations scattered through the coding region of the MEN1 gene have been detected in both familial and sporadic cases of MEN1 (5-10). In addition, somatic mutations of the same gene have been identified in a variable fraction of the sporadic counterparts of typical MEN1 neoplasms (parathyroid tumors, insulinomas and gastrinomas, pituitary adenomas and lung carcinoids) (11-17).

We report a new missense mutation of the MEN1 gene at codon 444 ( $\mathrm{T}$ to $\mathrm{C}$ ) in exon 9, resulting in a leucine to proline substitution (L444P) in an Italian kindred affected by MEN1.

\section{Patients and methods}

\section{Patients}

The proband (III-2; Fig. 1), a 50-year-old woman, was referred to our outpatient clinic in November 1996 for persistent hypercalcemia after subtotal parathyroidectomy (complete removal of the lower and upper right and of the lower left parathyroids; partial removal of the upper left parathyroid) for primary hyperparathyroidism (PHPT); she had been amenorrhoic since the age of 38 years and in October 1995 she underwent partial pancreatectomy for insulinoma. The physical examination was normal. The serum concentration of ionized calcium was $1.46 \mathrm{mmol} / \mathrm{l}$ (normal values 1.13$1.32 \mathrm{mmol} / \mathrm{l}$ ) and serum intact parathyroid hormone (PTH) was $267 \mathrm{pg} / \mathrm{ml}$ (normal values $10-65 \mathrm{pg} / \mathrm{ml}$ ). Prolactin was $500 \mathrm{pg} / \mathrm{ml}$ (normal values $2-18 \mathrm{pg} / \mathrm{ml}$ ). Glucose, insulin, gastrin and growth hormone $(\mathrm{GH})$ were normal. Neck ultrasound and MRI discovered two cervical masses close to the lower and upper left thyroid lobe. A pituitary CT scan showed a $2.5 \mathrm{~cm}$ mass with compression of the optic chiasm. In May 1997 a neck exploration was performed and two supranumerary left parathyroid glands were removed. Serum concentrations 


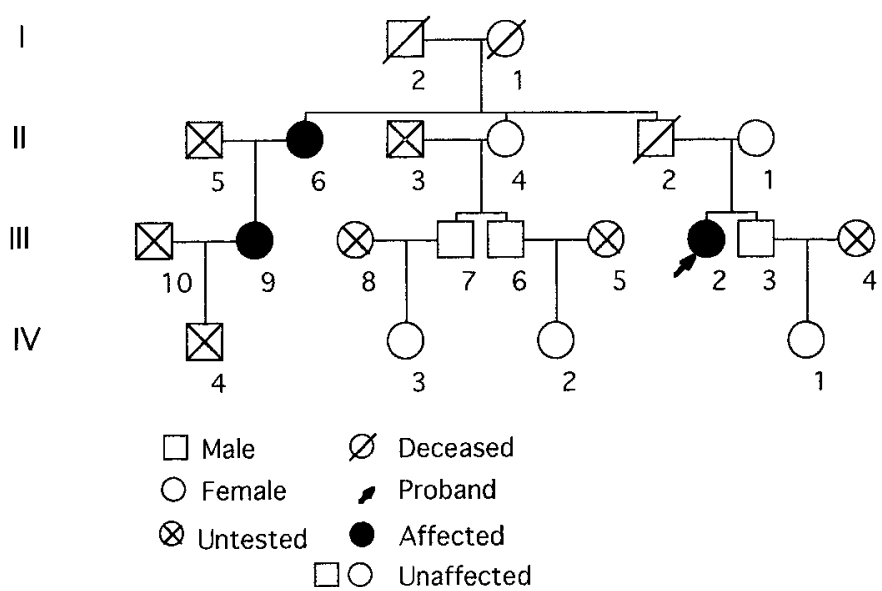

Figure 1 Pedigree of the family with MEN1.

of calcium and PTH became normal after surgery. In July 1997, a prolactin-secreting pituitary adenoma was successfully removed by transsphenoidal surgery.

Venous blood samples were obtained from ten members of the kindred (seven females and three males) for measurement of glucose, ionized calcium, intact PTH, prolactin, GH, insulin and gastrin. Two of them (II-6 and III-9, both females) had moderate hypercalcemia and elevated serum intact PTH (ionized calcium: 1.50 and $1.40 \mathrm{mmol} / \mathrm{l}$, PTH: 225 and $147 \mathrm{pg} / \mathrm{ml}$ respectively), indicating the presence of PHPT. GH, prolactin, glucose, insulin and gastrin were normal. No further clinical investigation could be performed in these subjects.

\section{DNA sequence analysis}

Genomic DNA was isolated from peripheral blood leukocytes of the proband and other family members by the phenol/chloroform method. The coding sequence, including nine coding exons and 16 splice junctions of the MEN1 gene (2) were amplified by PCR and subjected to direct sequencing. At least three different PCR amplifications from genomic DNA were sequenced on the double strand with sense and antisense primers. Primers are shown in Table 1. Reverse primers were biotinylated. PCR were performed in a final volume of $100 \mu \mathrm{l}$ containing $1 \mu \mathrm{g}$ DNA, $50 \mathrm{mmol} / \mathrm{l} \mathrm{KCl}, 10 \mathrm{mmol} / \mathrm{l}$ Tris-HCl, $\mathrm{pH} 8.3,1 \mathrm{mmol} / \mathrm{l}$ or $1.5 \mathrm{mmol} / \mathrm{l} \mathrm{MgCl}_{2}$ (for exons 2 and 3-10 respectively), $\quad 0.01 \%$ gelatin, $0.2 \mathrm{mmol} / \mathrm{l}$ deoxynucleotide trisphosphate, 5 U Taq polymerase (Cetus Corp., Berkeley, CA, USA) and $200 \mathrm{nmol} / \mathrm{l}$ of each primer. Dimethylsulfoxide (concentration 5\%) was included for exons 2 and 10. Annealing temperatures were 50 and $54{ }^{\circ} \mathrm{C}$ for exons 3-6 and 10, and 2 and 7-9 respectively. PCR products were purified on streptavidin-coated magnetic beads (Dynal, Oslo, Norway) and sequenced with Sequenase (version 2.0, USB, Cleveland, OH, USA) and ${ }^{35}$ S-labeled dATP- $\alpha S$ (Amersham International, Amersham, Bucks, UK).

Contamination problems were ruled out by including PCR control samples with no DNA as template.

\section{Confirmation of the mutation by restriction fragment length polymorphism (RFLP)}

For RFLP analysis, a 289 bp PCR fragment of exon 9 was amplified, using forward and reverse primers as indicated in Table 1, from the proband, all family members and 50 unrelated normal individuals. Aliquots $(10 \mu \mathrm{l})$ of purified PCR samples were incubated for $2 \mathrm{~h}$ at $37^{\circ} \mathrm{C}$ with the restriction enzyme EcoRII (GibcoBRL, Milan, Italy) or BlnI (Amersham International, Amersham, Bucks, UK). An adequate amount was separated in a $12 \%$ polyacrylamide gel and visualized with ethidium bromide.

Table 1 PCR primers of the MEN1 gene.

\begin{tabular}{lll}
\hline Exon & \multicolumn{1}{c}{ Sense primer } & \multicolumn{1}{c}{ Antisense primer } \\
\hline 2 & CCCCGGCCGAACCTGCCCGA & GAGGTGAGGTTGATGATTTGGAG \\
$3-6^{*}$ & GTTGGACATAGAGGGGTAAACAG & ACAGTTGACACAAAGTGAGACTGG \\
$7-8^{*}$ & CCTCAGCCAGCAGTCCTGTAGA & CCATCCCTAATCCCTACATGC \\
9 & CTGCTAAGGGTGAGAAGAGAC & AAAAGTCTGACAAGCCGTG \\
10 & GAGTTCCAGCCACTGGCCGG & GGTTTGATACAGACTGTACTCGG \\
\hline
\end{tabular}

* These exons were amplified as a single fragment. 


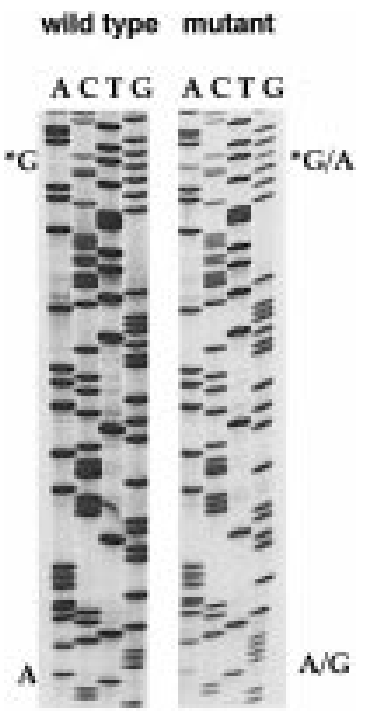

Figure 2 Antisense sequence analysis of exon 9. A to $\mathrm{G}$ base exchange in the antisense sequence, corresponding to a $T$ to $C$ exchange in the coding (sense) sequence at codon 444. In the mutant, the wild-type allele coexists with the mutated allele. The polymorphism D418D (a single substitution $G$ to $A$ ) is also shown (asterisk)

\section{Results}

The entire MEN1 gene coding region of the proband was analyzed by direct sequencing. A heterozygote T to C transition was present in exon 9, at codon 444. This substitution resulted in a leucine to proline (L444P) amino acid change (Fig. 2). The mutation created a new restriction site (EcoRII) and abolished a BlnI site from the wild-type sequence. This allowed us to obtain an independent confirmation of the missense mutation. The DNA wild-type sequence, containing one BlnI site, was associated with cleaved PCR products of 198 and $91 \mathrm{bp}$, whereas the mutant, which has lost the BlnI site, was associated with a PCR product of 289 bp (Fig. 3A). On the other hand, the mutation-associated new EcoRII restriction site created two PCR products of 117 and $91 \mathrm{bp}$ in the mutant DNA (Fig. 3B).

Taking advantage of the restriction site changes, DNA samples from the 10 available relatives and from 50 unrelated normal individuals were also submitted to the restriction enzyme analysis. As indicated in Fig. 3A and B the two subjects with PHPT (II-6 and III-9), both of paternal origin, had the expected restriction patterns associated with the L444P mutation in exon 9. The direct sequencing of this exon confirmed the mutation. These restriction enzyme changes were absent in all 50 unrelated normal subjects.
A

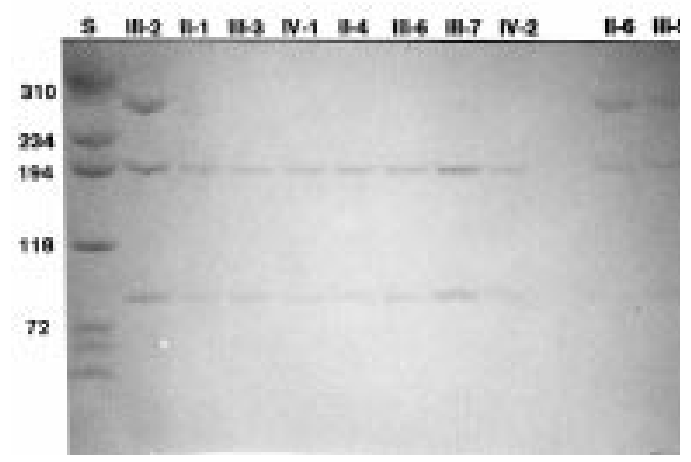

Figure 3 Detection of a mutation in exon 9 by restriction-enzyme analysis and gel electrophoresis. DNA sequence analysis of individuals III-2, II-6 and III-9 revealed a substitution at a second position ( $T$ to $C$ transition) of codon 444. The wild-type DNA sequence at codon 444 is CTA encoding for a leucine residue, whereas the mutant sequence is CCA encoding for a proline.

(A) The L444P mutation resulted in the loss of a BInl site. As illustrated, wild-type DNA samples showed two PCR products of 198 and $91 \mathrm{bp}$, whereas the mutant DNAs (III-2, II-6 and III-9) showed a single $289 \mathrm{bp}$ band. (B) The mutation also created a new EcoRII restriction site, resulting in the presence of cleaved PCR products of 117 and $91 \mathrm{bp}$ in the affected members (III-2, II-6 and III-9), whereas the wildtype DNA sequence is associated with a PCR product of $208 \mathrm{bp}$.

\section{B}

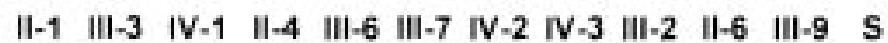


The proband and her mother, but not her paternal relatives carrying the $\mathrm{L} 444 \mathrm{P}$ mutation, also had a common polymorphism (D418D) $(2,8)$ (Fig. 2).

\section{Discussion}

Different mutations in the MEN1 gene in familial and sporadic MEN1 have been identified (5-10). In addition, somatic mutations of the same gene have been reported in sporadic parathyroid adenomas, sporadic neuroendocrine tumors of the gastroenteropancreatic system, pituitary tumors and lung carcinoids (11-16).

In this study, we have identified a new missense mutation in the MEN1 gene in an Italian kindred with MEN1. Affected individuals are heterozygous for leucine to proline substitution at codon 444 of the MEN1 gene. The affected members showed a variable phenotype (all had PHPT, only the proband had insulinoma and prolactinoma) confirming, as already reported, the lack of genotype-phenotype correlation within the same family (7). In this regard, previous studies have also shown that there is no correlation between the mutation type and localization with respect to MEN1 phenotype (5-8).

Nonsense mutations, frameshift deletions or insertions have been reported in the majority of MEN1 kindred so far studied (5-10). These changes are likely to result in major alterations and functional loss of the MENIN protein and are in keeping with the proposed role of the MEN1 gene as a tumor-suppressor gene (18). On the other hand, in the absence of information about function and three dimensional structure of MENIN protein (4) we cannot measure the consequences of missense mutations. In the study of Agarwal et al. (5) 4 of the 13 missense mutations of MENIN protein were gain of proline, including a leucine for proline substitution (L266P) in exon 6. These authors have pointed out that proline changes were not likely to be benign polymorphisms since all of them were in high-complexity regions and all but one in regions likely to be an alpha helix. In agreement with this concept is the absence of the L444P mutation in 50 unrelated normal individuals.

The mutation described in the present study also resulted in the loss of the BlnI restriction site and in the creation of a new restriction site (EcoRII) in exon 9 which facilitated the detection of two additional family members (II-6 and III-9) carrying the mutation. In both cases direct sequencing confirmed the L444P substitution.

A common polymorphism (D418D) $(2,8)$ in exon 9 was present in the proband and her mother, but not in the two paternal relatives carrying the L444P mutation. The finding that this polymorphism was present only in the proband but not in the other affected members indicates that the L444P mutation and the D418D polymorphism are on different alleles.

In conclusion, we have described a new MEN1 gene mutation in exon 9 in an Italian kindred which extends our knowledge concerning the variety of genetic abnormalities associated with familial MEN1 and may contribute to a better understanding of the functional role of MENIN protein and its role in the pathogenesis of MEN1-associated tumors.

\section{Acknowledgements}

This work was supported by grants from the University of Pisa (Fondi di Ateneo), from the Ministero dell'Università e Ricerca Scientifica e Tecnologica (40\%) (Rome, Italy), Target Project: Biologia e Patologia delle Interazioni Cellula-Matrice, subproject Osteoporosi e Osteopatie Metaboliche, and from the European Community: project NuFiSa (F14CCT960002) and project INCO-Copernicus (IC 15-CT 960310).

\section{References}

1 Thakker RV. Multiple endocrine neoplasia type 1. In Endocrinology, ch 3, pp 2815-2831. Ed. LJ DeGroot. Philadelphia: WB Saunders, 1995.

2 Chandrasekharappa SC, Guru SC, Manickam P, Olufemi SE, Collins FS, Emmert-Buck MR et al. Positional cloning of the gene for multiple endocrine neoplasia-type 1. Science $1997276404-$ 407.

3 Lemmens I, Van de Ven WJM, Kas K, Zhanh CX, Giraud S, Wautot $\mathrm{V}$ et al. Identification of the multiple endocrine neoplasia type 1 (MEN1) gene. Human Molecular Genetics 19976 1169-1175.

4 Guru SC, Goldssmith PK, Lee Burns A, Marx SJ, Spiegel AM, Collins FC et al. Menin, the product of the MEN1 gene, is a nuclear protein. Proceedings of the National Academy of Sciences of the USA $1998951630-1634$.

5 Agarwal SK, Kester MB, Debelenko LV, Heppner C, Emmert-Buck MR, Skarulis MC et al. Germline mutations of the MEN1 gene in familial multiple endocrine neoplasia type 1 and related states. Human Molecular Genetics 19976 1169-1175.

6 Tanaka C, Yoshimoto K, Yamada S, Nishioka H, Ii S, Moritani M et al. Absence of germline mutations of the multiple endocrine neoplasia type 1 (MEN1) gene in familial pituitary adenoma in contrast to MEN1 in Japanese. Journal of Clinical Endocrinology and Metabolism 199883 960-965.

7 Mayr B, Apenberg S, Rothamel T, Von Zur Muhlen A \& Brabant G. Menin mutations in patients with multiple endocrine neoplasia type 1. European Journal of Endocrinology 1997137 684-687.

8 Basset JHD, Forbes SA, Pannet AAJ, Lloyd SE, Christie PT, Wooding $\mathrm{C}$ et al. Characterization of mutations in patients with multiple endocrine neoplasia type 1. American Journal of Human Genetics 199862 232-244.

9 Kishi M, Tsukada T, Shimizu S, Futami H, Ito Y, Kanbe M et al. A large germline deletion of the MEN1 gene in a family with multiple endocrine neoplasia type 1. Japanese Journal of Cancer Research 199889 1-5.

10 Teh BT, Kytola S, Farnebo F, Bergman L, Wong FK, Weber G et al. Mutation analysis of the MEN1 gene in multiple endocrine neoplasia type 1 , familial acromegaly and familial isolated hyperparathyroidism. Journal of Clinical Endocrinology and Metabolism $1998832621-2626$.

11 Heppner C, Kester MB, Agarwal SK, Debelenko LV, Emmert-Buck MR, Guru SC et al. Somatic mutation of the MEN 1 gene in parathyroid tumours. Nature Genetics 199716 375-378.

12 Toliat MR, Berger W, Ropers HH, Neuhaus P \& Wieddenmann B. Mutations in the MEN1 gene in sporadic neuroendocrine tumours of gastroenteropancreatic system. Lancet 19973501223.

13 Zhuang Z, Vortmeyer AO, Pack S, Huang S, Pham TA, Wang C et al. Somatic mutations of the MEN 1 tumor suppressor gene in 
sporadic gastrinomas and insulinomas. Cancer Research 199757 $4682-4686$.

14 Zhuang Z, Ezzat SZ, Vortmeyer AO, Weil R, Olfield EH, Park WS et al. Mutations of the MEN1 tumor suppressor gene in pituitary tumors. Cancer Research 199757 5446-5451.

15 Debelenko LV, Brambilla E, Agarwal SK, Swalwell JI, Kester MB, Lubensky IA et al. Identification of the MEN1 gene mutations in sporadic carcinoid tumors of the lung. Human Molecular Genetics $199762285-2290$

16 Farnebo F, Teh BT, Kytola S, Svensson A, Phelan C, Sandelin K et al. Alterations of the MEN1 gene in sporadic parathyroid tumors. Journal of Clinical Endocrinology and Metabolism 199883 2627-2630.
17 Carling T, Correa P, Hessman O, Hedberg J, Skogseid B, Lindberg D et al. Parathyroid MEN1 gene mutations in relation to clinical characteristics of nonfamilial primary hyperparathyroidism. Journal of Clinical Endocrinology and Metabolism 199883 29602963.

18 Larsson C, Skogseid B, Oberg K, Nakamura Y \& Nordenskjold M. Multiple endocrine neoplasia type 1 gene maps to chromosome 11 and is lost in insulinoma. Nature 1988332 85-87.

Received 30 November 1998

Accepted 22 December 1998 